\title{
The Internal and External Manifestations of Cultural Nationalism: A Borobudur Case Study
}

Chelsie Baldwin

The Australian National University

Abstract: This essay investigates how the Buddhist monument Borobudur has been used to develop Indonesia's national identity through the process of cultural nationalism. Indonesia is an expansive archipelago that unites a diverse range of ethnic and religious groups under a singular national identity. Its heterogeneous cultural heritage has been appropriated since gaining independence in 1945 to unite the state under a collective history. The Borobudur temple complex was constructed by the Sailendra dynasty in c. 800 CE. A minority of Indonesians hold a religious affinity to the site, and fewer still are descendants of the Sailendra dynasty. Yet the temple is considered a national monument of Indonesian cultural heritage. The construction of a shared past has been studied as a broad concept in relation to nationalist ideology. However, considering the specific case study of Borobudur within the context of cultural nationalism in Indonesia allows for an in-depth consideration of the malleability of cultural monuments to meet a specific agenda. This article aims to highlight the significance of cultural consciousness to an understanding of how nationalist ideology is disseminated in Indonesia. It will consider how successive Indonesian governments mobilised Borobudur to suit a sociopolitical purpose, and how these were manifested internally, within the Indonesian nation, and externally, within the international community.

The development of cultural nationalism in Indonesia is bilateral. It denotes the unification of heterogeneous populations within national borders, while concurrently asserting a place for the Indonesian nation-state within the global community. The seemingly paradoxical manifestations of internal and external Indonesian nationalism can be comprehended by exploring the cultural nationalist discourse surrounding the Buddhist stüpa, Borobudur. Constructed in c. $800 \mathrm{CE}$ under the Sailendra dynasty, 
Borobudur fell into a state of disrepair with the spread of Islam across the archipelago in the fifteenth century. ${ }^{1}$ It was subsequently disinterred during the colonial period through archaeological inquiry. While these historical implications may ostensibly confine Borobudur's contemporary role to that of an archaeological spectacle, this article contends that the modularisation of the site that occurred during the twentieth century has facilitated its mobilisation for the perpetuation of a national Indonesian identity. It should, however, be considered that there is, in practice, considerable variety in how Indonesians assert and assimilate nationalist ideas. Nationalist ideology is unique in its manifestations both within a nation itself, and within the global community. Accordingly, it can be described in comprehensive terms. By considering the manifestations of both internal and external nationalism through a historiographical survey of Borobudur, the temple's role in the perpetuation of a national Indonesian identity will be made explicit. This will thereby posit a deeper understanding of the historical manifestations of cultural politics in Indonesia.

\section{Nations, Nationalism and Culture: Definitions and Concepts}

An understanding of the historiographical concepts and definitions of nation and nationality are essential to the consideration of cultural nationalism presented in this article. The concept of the nation, and its various sub-branches, are terms that are not inherently self-evident. These terms are limited by virtue of their interpretation. Benedict Anderson defines a nation as an imagined political community that is both limited and sovereign. ${ }^{2}$ The limitations Anderson refers to denote the fixed yet changeable geographic borders, beyond which other nations lie. Anderson's concept of sovereignty, born from Enlightenment and Revolutionary thought, inherently necessitates the nation-state to be free, albeit in some instances under a religious structure. ${ }^{3}$ The nationstate in an administrative sense is not inherently bound by shared

1 R. E. Jordaan, 'The Sailendras: The Status of the Ksatriva Theory, and the Development of HinduJavanese Temple Architecture', Bijdragen Tot De Taal-, Land-En Volkenkunde 155, no. 2 (1999): 210, doi.org/10.1163/22134379-90003875.

2 Benedict R. O'G. Anderson, Imagined Communities: Reflection on the Origin and Spread of Nationalism (London: Verso, 1983), 7.

3 Anderson, Imagined Communities, 7. 
ideology or ethnicity. Thus, a cooperative legitimacy has to be established for nationhood to unite diverse groups under a shared administration. The Republic of Indonesia typifies this diversity. The Indonesian archipelago subsumes groups of different religious, linguistic and cultural ideologies over a vast geographical region. For the Indonesian nation-state to exist cooperatively in spite of these differences, an emotional legitimacy towards the nation must be established. Within this case study the way in which Borobudur has been mobilised behind Indonesian nationalism to perpetuate this legitimacy will be considered.

Anderson articulates how narratives are established to consolidate the nation-state through a shared past. He suggests that 'amnesias' - a loss of collective memory brought about by a collective change in consciousness (e.g. colonial occupation or independence)—are susceptible to being filled by narratives set in a 'homogeneous, empty time'. ${ }^{4}$ Eric Hobsbawm considers these narratives through the concept of 'invented traditions'. He considers that invented traditions are legitimised by historic reference and repetition, and utilised to unite diverse communities through a shared national identity. ${ }^{5}$ Anderson suggests that these historic references can be remembered, adapted or invented to meet a specific agenda. ${ }^{6}$ He argues that the emotional legitimacy attributed to a nation (by both its citizens and the global community) is apparent when considered within the context of cultural heritage. Through a dual consideration of Anderson's and Hobsbawm's concepts of imagined communities and invented traditions, respectively, this case study of Borobudur will allow for a means of testing and extending their theoretical positions.

The emotional legitimacy attributed to the Republic of Indonesia, and the sentiments of nationhood and nationalism that manifest from this legitimacy, can be considered through the concept of cultural nationalism. Cultural nationalism is the process by which the aesthetic manifestations of human achievement are mobilised to legitimise and glorify a specific nation-state. It is imperative to the process of national unification as it establishes a shared affiliation (invented or otherwise) to an aesthetic tradition. Considerations of Borobudur tend to be limited to the aesthetic or archaeological implications that can be deduced through

4 Anderson, Imagined Communities, 24.

5 Eric Hobsbawm, 'Introduction: Inventing Traditions', in The Invention of Tradition, ed. Eric Hobsbawm and Terence Ranger (Cambridge: Cambridge University Press, 1983), 4.

6 Anderson, Imagined Communities, 179. 
the site itself. These readings of the site are articulated in A. Foucher's The Beginnings of Buddhist Art and Other Essays in Indian and CentralAsian Archaeology, Luis Gomez and Hiram W. Woodward's Barabudur: History and Significance of a Buddhist Monument and F. D. K. Bosch's Selected Studies in Indonesian Archaeology to name but a few. The tendency to omit the sociopolitical implications of the Borobudur temple within successive societies necessitates this study. By departing from the conventional interpretation of Borobudur as an art object in favour of an examination of its relation to its material culture, this study will facilitate understanding of how the Republic of Indonesia manifests its nationalist discourse through its appreciation of an esteemed monument of cultural significance: the Borobudur temple.

\section{Internal Nationalism: The Unification of Indonesia}

The disinterment of ruins, and their subsequent transformation into archaeological monuments, has created a united past beyond colonial occupation. The visual legacy of the Sailendra Empire is emphatic. At the acme of its power, the Sailendra Empire is thought to have significantly subsumed the South-East Asian mainland and the Indo-Malay archipelago. Following the Mahāyāna Buddhist tradition, the Sailendras erected a number of religious monuments throughout their domain: Borobudur was among them.

A cosmogram of concentric square and circular stone terraces, Borobudur's pyramidal structure mimics the surrounding mountainous landscape of the Central Javanese region. H. N. Seiburgh was the first to consider the site for its cosmogram architecture, and illustrated a series of drawings mapping the temple floor plan in 1837-38. ${ }^{8}$ The temple structure is consistent with the mandala of Buddhist symbolic architecture and design. Borobudur's floor plan encourages a circumambulation of the site, starting at a disinterred basement. The square terraces of the lower temple form four galleries, depicting a succession of Jätaka, avadāna and sütra that inform the experience of the site. The action of pilgrimage is mirrored in the reliefs of the second gallery, which depict the journey of

7 Jordaan, 'The Sailendras', 210.

8 H. N. Seiburgh, Plattegrond van de Borobudur, 1838-1837, ink on paper, $35.5 \times 51 \mathrm{~cm}$, Leiden, Museum of Ethnology, RV-37-903-7. 
Sudhana as articulated in the Gandavyüha sütra, composed in Sanskrit by the fourth century. A series of illustrations from around 1814 depict the architectural details of the second gallery. ${ }^{9}$ The illustrations are attributed to Dutch engineer H. C. Cornelius and his team. There are five iconographic depictions of the wisdom of Buddha represented at Borobudur, with four articulating one of the four sides of the temple structure. These Buddhas are illustrated in Drawing of the Five Buddhas Depicted on Candi Borobudur (1837-38) by H. N. Seiburgh. Akshobya is illustrated on the eastern temple wall, Ratnasambhava articulates the southern, Amitabha the western and Amoghasiddhi the northern wall. Above the didactic levels are three stages of circular terraces. The terraces are adorned with 72 bell-shaped stüpa (hemispherical structures typical of Buddhist architecture). Inside these stüpa, the fifth Buddha, Vairocana, is conscealed, obscured in the most part by stūpa wall. A latticed fenestration of the stüpa (diamond on the lower terraces and square on the upper) reveals a glimpse of Vairocana inside. The implications of archaeology, pillaging, tourism and time have resulted in damage to a number of the stūpa, and the Buddhas enclosed to varying degrees. At the acme of the Borobudur temple is a central stüpa with an unfinished Buddha inside. The Borobudur temple typifies an iconographic depiction of Buddhist Mahāyāna philosophy.

The spread of Islam across the archipelago by the fifteenth century cultivated an attitude of superstition towards the monument by the Central Javanese people. The significance of Hindu-Buddhist temples across the region was lost to ideological amnesia, and Borobudur fell into a state of disrepair until colonial occupation. Dutch trade arrived in the region during the late sixteenth century, reigniting the prestige with which Borobudur was considered through the colonial affinity towards archaeological investigation. The condition of the stüpa as the Dutch revived it is depicted in a series of photographs in the National Museum of World Cultures in the Netherlands. The images juxtapose the mountainous landscape of the region with the rubble of the fragmented monument. ${ }^{10}$

9 H. C. Cornelius, Hoekfragment van de Borobudur, 1814, ink on paper, $20 \times 31 \mathrm{~cm}$, Leiden, Museum of Ethnology, RV-1403-3563.

10 Unknown, Uitzicht Vanaf de Borobudur, 1890-1910, photograph, 16.2 × $21.9 \mathrm{~cm}$, Netherlands, National Museum of World Cultures, 7082-nf-332-9; unknown, De Borobudur, 1890-1910, photograph, 15.7 x $21.7 \mathrm{~cm}$, Netherlands, National Museum of World Cultures, 7082-nf-332-10; unknown, De Borobudur l.o. Nr 87, 1890-1910, photograph, $16.2 \times 21.8 \mathrm{~cm}$, Netherlands, National Museum of World Cultures, 7082-nf-332-11. 
Affinity with archaeological inquiry during this period was not unique to the colonial experience within Indonesia nor colonially occupied lands more broadly. Within Great Britain, for example, the archaeological excavation of Stonehenge was used as a marker of cultural uniqueness. ${ }^{11}$ The Indonesian archipelago was united under Dutch hegemony and, by the 1920s, the Dutch East Indies was at its geographical apogee. The geographical boundaries at the acme of the Dutch East Indies most closely delineate the region that would become the independent Republic of Indonesia in $1945 .^{12}$ Dutch colonisers used archaeological monuments to create alternative legitimacies for their regime in this region.

'Rediscovered' under the authority of Sir Thomas Raffles in 1814, Borobudur was subsequently surveyed through a number of statesanctioned commissions. ${ }^{13}$ German photographer Adolph Schaefer was commissioned to produce daguerreotypes of the site in 1845. In 1851, under the authority of F. C. Wilsen, a systematic study of Borobudur's bas-reliefs was produced. Dr C. Leemans, in his role as director of the Public Museum of Antiquities, Leiden, published Wilsen's handwritten recollections and descriptions of this study, as well as documents by J. F. G. Brumund, in the first academic manuscript on Borobudur in $1874 .{ }^{14}$ Javanese court photographer, Kassian Cephas, produced a thorough photographical survey of the site prior to the turn of the nineteenth century. Cephas's photographs from this series, Bas-Reliëfs van de Verborgen Voet van de Borobudur [Bas-Reliefs of the Hidden Foot of the Borobudur], can be seen in the Museum of Ethnology collection in Leiden. ${ }^{15}$ The collection and publication of these sources through Dutch institutions is significant. These studies revived the ancient prestige of the site and allowed the Dutch metropole to emerge as the guardian of generalised local traditions within the colony. Through this process Borobudur was assimilated into the map of the colony, linking its prestige to the colonial homeland and

11 Linda Marie Zimmerman, Representations of Stonehenge in British Art (1300-1900): Antiquity, Ideology, and Nationalism (Ann Arbor: Stanford University, 1997).

12 Bernard Lewis, History: Remembered, Recovered, Invented (Princeton: Princeton University Press, 1975), 12; Anderson, Imagined Communities, 11.

13 Marieke Bloembergen and Martijn Eickhoff, 'Exchange and the Protection of Java's Antiques: A Transnational Approach to the Problem of Heritage in Colonial Java', The Journal of Asian Studies 72, no. 4 (2013): 893, doi.org/10.1017/S0021911813001599.

14 C. Leemans, Bôrô-Budour: Dans Lỉle de Java, Dessiné par ou sous la direction de Mr F. C. Wilsen, avec texte descriptif et explicative, rédigé, d'apres les mémoires manuscrits et imprimés de Mm. F. C. Wilsen, J. F. G. Brumund et autres documents (Leiden: E.J. Brill, 1874).

15 K. Céphas, Bas-Reliëfs van de Verborgen Voet van de Borobudur, 1890-1891, photolithograph on paper, 16 x 22 cm, Leiden, Museum of Ethnology, RV-1403-3788-1 - RV-1403-3788-160. 
creating a historical depth to the imposing regime. ${ }^{16}$ An example of the mapping process is evident in Folio Atlas 553 in the Grand Atlas of the Dutch East India Company. Engineer H. C. Cornelius described the map, presently in the collection of the Museum of Ethnology, Leiden, as a figurative plan of the location of Borobudur. ${ }^{17}$ The map in reality shows little topographical data, with roads, mountains and rivers scarcely and inaccurately depicted on the map. Yet, its appearance in the Grand Atlas of the Dutch East India Company asserted Borobudur as regalia for the colonial state. The charting of occupied territories through this process established unified boundaries, thereby collating diverse communities under one administrative centre.

Archaeological practice also enabled the restoration of ruins, transforming them into regalia for the colonial state. This is apparent through a series of studies by H. N. Seiburgh. Seiburgh produced an illustrated survey of Borobudur, as well as the Central Javanese temples of Prambanan and Candi Sewu, at the time of their excavation by colonial archaeologists. ${ }^{18}$ The restoration of Borobudur in the early twentieth century facilitated its nationalistic reinterpretation. Converted through a process of 'museumisation', the modularised site could be adapted as a state emblem irrespective of regime change. ${ }^{19}$ The Dutch added fences, manicured lawns, explanatory tablets and promenades to the complex. These additions to the site are depicted in the aerial photograph Luchtfoto van de Borobudur (1921-39) taken by the Luchtvaart Afdeeling [the Aviation Department of the Dutch East Indies], which displays the roads and lawns surrounding Borobudur at the time. ${ }^{20}$ The secularisation of the site with the prohibition of religious ceremonies and pilgrimages augmented this process. ${ }^{21}$ Through the archaeological processes of mapping and museum-isation,

16 Marieke Bloembergen and Martijn Eickhoff, 'Conserving the Past, Mobilizing the Indonesian Future: Archaeological Sites, Regime Change and Heritage Politics in Indonesia in the 1950s', Bijdragen tot de Taal-, Land-en Volk 167, no. 4 (2011): 408, doi.org/10.1163/22134379-90003578.

17 Unknown, Kaart, 1814, ink on paper, 32 x 50 cm, Leiden, Museum of Ethnology, RV-1403-3550.

18 H. N. Sieburgh, Plattegrond van de Candi Sewu, 1837-1838, paper, 51.5 x $35.5 \mathrm{~cm}$, Netherlands, Nationaal Museum van Wereldculturen, RV-37-903-12; H. N. Sieburgh, Halve opstand en doorsnede van de hoofdtempel van Loro Jonggrang $51.5 \times 35.5 \mathrm{~cm}$, Netherlands, Nationaal Museum van Wereldculturen, RV-37-903-15.

19 Anderson, Imagined Communities, 181.

20 Luchtvaart Afdeeling, Luchtfoto van de Borobudur, 1921-1939, cellulose acetate photograph on paper, 9 x $12 \mathrm{~cm}$, Amsterdam, Tropenmuseum, TM-10015635.

21 Anderson, Imagined Communities, 181. 
Borobudur became modular-capable of conforming to a multiplicity of ideological agendas. ${ }^{22}$ The Dutch regime had thereby set the precedent for the mobilisation of Borobudur by their independent successors.

The ideological mobilisation of Borobudur in post-independence Indonesia exhibited marked continuities with its colonial predecessors. The government of the newly independent nation attempted to imbue on its citizens that they shared a 'common past, a unified present, and a hopeful future' in an attempt to supplant the potentially tenuous loyalty often afforded to administrations of newly established nations. ${ }^{23}$ The geographic expanse of the Indonesian archipelago-coalescing diverse communities within its national borders-ensured that a legitimate collective history was absent. The collective experience of the Indonesian nation-state in its geographic entirety amounts to colonial oppression and the subsequent struggle for independence. ${ }^{24}$ Shared histories therefore had to be invented beyond this to establish a comprehensive and collective national past. ${ }^{25}$ The inheritance of an already modularised and secularised archaeological monument afforded Indonesian nationalist proponents the ability to perpetuate cultural nationalism that utilised the Borobudur site. ${ }^{26}$ This manifestation of cultural nationalism was multidimensional, delineating a shared struggle in addition to a shared cultural history.

The Republic of Indonesia upheld a particular vision of its colonial past that extended beyond historical progression. The anti-colonial sentiments employed by nationalists in the Dutch East Indies were sustained into the period following independence to unite the archipelago. ${ }^{27}$ The imposed authority of the Dutch East Indies subsumed an array of communities who had not previously shared a unified political identity. Examples

22 Hobsbawm, 'Inventing Traditions', 4.

23 Michael Wood, Official History in Modern Indonesia: New Order Perceptions and Counterviews (Leiden: Brill, 2005), 2.

24 Hobsbawm, 'Inventing Traditions', 2.

25 Hobsbawm, 'Inventing Traditions', 4.

26 National identity in Indonesia has taken numerous forms beyond the cultural nationalism perpetuated through the case study of Borobudur. Brown, for example, considers the implications of the Indonesian National Games on the construction of nationalism in autonomous Indonesia. While discourses such as these fall beyond the scope of this case study, they are of significance to the cultural nationalism propagated in the Indonesian nation state. Colin Brown, 'Sport, Modernity and Nation Building: The Indonesian National Games of 1951 and 1953', Bijdragen Tot De Taal-, Land- En Volkenkunde 164, no. 4 (2008): 431, doi.org/10.1163/22134379-90003650; Joshua Barker, 'Beyond Bandung: Developmental Nationalism and (Multi)cultural Nationalism in Indonesia', Third World Quarterly 29, no. 3 (2008): 527, doi.org/10.1080/01436590801931496.

27 Edward Aspinall, 'The New Nationalism in Indonesia', Asia \& the Pacific Policy Studies 3, no. 1 (2015): 76, doi.org/10.1002/app5.111. 
of this can also be seen with British colonies in Zimbabwe, Botswana and Ghana; and German colonies in Tanzania. In these instances, as in Indonesia, colonialism enabled a recognisable and figurative authority over annexed spaces as a means of legitimising authority and bolstering unity. Political leaders of these nations following independenceBotswana's Sir Seretse Khama, Ghana’s President Kwame Nkrumah and Tanzania's President Julius Nyerere-have each expressed sentiments regarding the need to recover an 'African past'. ${ }^{28}$ Zimbabwe is named after the regions most renowned archaeological site, Great Zimbabwe. ${ }^{29}$ This asserts a connection between the nation-state and the great empire of the past. These sentiments echo the response to the colonial experience in independent Indonesia. Sukarno, Indonesiàs first president (194567) and a nationalist proponent, generalised the experience of colonial occupation, suggesting that Indonesia had endured 350 years of colonialism (despite the fact that the region was geographically united only in the 1920s, and administratively united as an independent nation-state in 1945). ${ }^{30}$ Sukarno thereby extended Indonesia's national history beyond its twentieth-century origins, creating historic depth to the unification of the nation. The logical continuation of this is that the ancient past that predated colonial occupation united the Indonesian nation. Sukarno considered the geographical scope and political power of the Sailendra dynasty impressive, as it delineated an idyllic past that both preceded and contrasted the oppression of Dutch control. ${ }^{31}$ By implying connections between the Republic of Indonesia and the Sailendra Empire, a unified national history was established. This pre-colonial memory, while not historically consistent, united the communities that fell within the territorial boundaries of the late Dutch East Indies under a shared past.

An invented narrative confined largely to archaeological histories, as outlined by Anderson, has filled this historical amnesia. ${ }^{32}$ These narratives can be considered through Hobsbawm's concept of repetition and reference to the past as a means of legitimising invented traditions. Reference to Borobudur's collaborative history is apparent in a speech

28 Paul Lane, 'Possibilities for a Postcolonial Archaeology in Sub-Saharan Africa: Indigenous and Usable Pasts', World Archaeology 43, no. 1 (2011): 12, doi.org/10.1080/00438243.2011.544886.

29 Brian Raftopoulos and Alois Mlambo. Becoming Zimbabwe. A History from the Pre-Colonial Period to 2008 (Harare: Weaver Press, 2009): xix, doi.org/10.2307/j.ctvk3gmpr.

30 Anderson, Imagined Comunities, 11; Wood, Official History in Modern Indonesia, xii.

31 Wood, Official History in Modern Indonesia, 41.

32 R. E. Jordaan, 'Why the Sailendras Were Not a Javanese Dynasty', Indonesia and the Malay World 34, no. 98 (2006): 25, doi.org/10.1080/13639810600650711. 
made by Tien Suharto - the wife of Indonesia's second president, Suharto (1967-98) — to the Working Conference of Provincial Governors on 1 December 1975:

If in the olden days, our ancestors worked co-operatively together to create the Borobudur, which now commands the attention of the whole world, today we too can work co-operatively to build the Taman Mini Indonesia Indah (Beautiful Indonesia in Miniature Project) [A culture-based recreational park that encapsulates the collections of Indonesian architecture, clothing, and performing arts]..$^{33}$

Tien Suharto used language that conveyed a collaborative and glorified history through mention of ancestors, cooperation and the global importance of the Borobudur monument. The audience of provincial governors is significant, as Hobsbawm posits that imagined historical discourse emanates from top-down approaches. ${ }^{34}$ The monumentality of Borobudur is further reified through its presence in the Beautiful Indonesia in Miniature Project more generally, as its inclusion in the park legitimises its centrality to the Indonesian past through its significance to Indonesian cultural tourism. The equivocal nature of Tien Suharto's assertion is evocative of a fabricated past, which attests to the mobilisation of Borobudur behind a national identity that extends beyond historical and geographical continuity.

Nationalist sentiments and self-censorship were not limited to political discourse; Indonesian historians also recorded them in an academic capacity. Dutch involvement in the Indonesian Archaeological Service continued until 1957 and, further to this, the writings and teachings of Dutch scholars were seminal for the early generations of Indonesian archaeologists and historians. ${ }^{35}$ Dutch archaeologist Bernet Kempers was director of the service until 1953. The Indonesian archaeologists and directors who inherited the Indonesian Archaeological Service, such as R. Soekmono and Satyawati Soerjono Soerjo, were educated by their Dutch predecessors. As a consequence, understanding of the Sailendra dynasty's origin is convoluted by historiographic uncertainty and invented histories inherited by colonial archaeological practice. Palpable

33 Benedict R. O'G. Anderson, Language and Power: Exploring Political Cultures in Indonesia (Ithaca: Cornell University Press, 1990), 176.

34 Hobsbawm, 'Inventing Traditions', 9.

35 Bloembergen and Eickhoff, 'Conserving the Past', 430. 
implications and imaginings from Borobudur itself are preferred over academic readings of the site, as they could easily illustrate the nationalist vision. ${ }^{36}$ Indonesian archaeologist and historian Soekmono infers abstract connections between the Indonesian citizenry and the Sailendra dynasty:

The modern Indonesians are directly descended from the builders of the candi [Hindu-Buddhist temple], and are therefore heirs to these remains of the noble works of their ancestors. Such a conclusion is hard to disagree with: the candi still occupy a special place in the hearts of the Indonesian people. Their value is difficult to explicate, for it is not a rational, normative quality but an emotional and spiritual one, and can only be truly felt by the heirs themselves. ${ }^{37}$

Soekmono's assertion that the affinity felt by Indonesian visitors to Hindu-Buddhist temples is a testament to the Javanese builders of the sites exemplifies Hobsbawm's definition of invented traditions. An implication of this assertion is that the already limited understanding of the Sailendra dynasty's origins are further convoluted. This facilitates the acceptance of such invented histories, as the lack of extant evidence available from the sites becomes diluted in historiographic writings of the invented histories. Therefore, a consideration of Borobudur highlights the unification of heterogeneous populations within national borders not only ideologically but also historiographically.

The national historical discourse associated with Borobudur was disseminated through the reproducibility of the site inherited from colonial archaeological survey. Technological developments in print and photography made this reproducibility possible, while the dissemination occurred as a continuation of the colonial tendency to present Borobudur as state regalia. Through the production of technically sophisticated archaeological reports, photographic and lithographic reconstructions, and illustrated books for educational and public consumption, Borobudur was iconised to promote an identifiable signifier of the riches of the Dutch colony ${ }^{38}$ A collection of 'early Indonesian postcards' collated by Leo Haks and Steven Wachlin highlights how an iconised Borobudur was disseminated globally during colonial occupation through this

36 Bloembergen and Eickhoff, 'Conserving the Past', 431.

37 R. Soekmono, 'The Candi as a Cultural Pusaka', in Art of Indonesia, ed. H. Soebadio (London: Tauris Parke, 1993), 51.

38 Anderson, Imagined Communities, 181. 
medium. With the postcards published by companies such as Firma Sigrist and Grand Hotel 'De Djokja' (1918), ${ }^{39}$ this collection articulates the importance the Dutch colonial power attached to the dissemination of Borobudur as an important cultural symbol.

Manifestations of Borobudur as an icon following independence are multifaceted continuations of this phenomenon. Images of the site are depicted on postage stamps, the national currency, modern and contemporary Indonesian art, and school textbooks. Artists central to Indonesia's artistic canon, such as Affandi and Srihadi Sudarsono, explored iconographic representations of Borobudur in multiple iterations throughout their oeuvres. ${ }^{40}$

From a contemporary perspective, the exhibition of Dyan Anggraini's series entitled Perempuan (di) Borobudur [Women of the Borobudur Temple] (20 February - 5 March 2018) promotes this iconological reading. The exhibition, displayed at Galeri Nasional Indonesia [National Gallery of Indonesia] offers a social critique of the women supporting the temple through an iconological articulation of the working conditions they are subjected to. ${ }^{41}$ The display of the exhibition at the Galeri Nasional Indonesia is a testament to the centrality of Borobudur to Indonesia's national identity. The marketisation of the monument is a modern progression of the phenomenon of dissemination through iconisation. Borobudur-themed hotels and fast food chains mark the unconscious lineal descendant of colonial archaeology. ${ }^{42}$ By repeatedly mobilising Borobudur as a national symbol both at an institutional and societal level, the site is easily recognisable as an Indonesian monument maintained by a unified Indonesian society.

As Islam maintains its status as religious majority in Indonesia, the role of Borobudur in the perpetuation of cultural nationalism has at times been contentious. In 1985 Islamic extremists bombed Borobudur. ${ }^{43}$

39 Leo Haks and Steven Wachlin, Indonesia: 500 Early Postcards (Singapore: Archipelago Press, 2004), 164-65.

40 Sardjana Sumichan, Affandi (Jakarta: Bina Lestari Budaya Foundation, 2007), 313; Srihadi Sudarsono, Borobudur II, 1982, oil on canvas, 95 x $140 \mathrm{~cm}$, Galeri Nasional Indonesia, Jakarta.

41 Suwarno Wisetrotomo, Dyan Anggraini: Perempuan (di) Borobudur (Jakarta: Galeri Nasional Indonesia, 2018).

42 Anderson, Imagined Communities, 181.

43 Mark P. Hampton, 'Heritage, Local Communities and Economic Development', Annals of Tourism Research 32, no. 4 (2005): 737; Anonymous, 'Asia: Arrest of a Smiling Extremist; Terrorism in Indonesia', The Economist 32 (14 August 2010): 396. 
While the incident had no causalities, the bombing damaged nine stūpas. ${ }^{44}$ Authorities used the attack as justification for vigilance against the Islamic militancy, attributing the bombing to the 'extreme right'. ${ }^{45}$ Perpetrators of the attack were purportedly acting in retaliation for the Tanjung Priok massacre of September 1984. ${ }^{46}$ Official reports suggest that the incident resulted in 24 fatalities. ${ }^{47}$ President Suharto's condemnation of the attack in a United Press International article published on the day of the bombing is indicative of the administrative response:

President Suharto denounced those responsible, saying they 'stand for people who have no sense of national pride, considering that the Borobudur temple constitutes a national, even a world monument.48

Suharto's statement secularises the incident, placing precedence on the monumentality of Borobudur over the religious implications of the attack. Bloembergen suggests political leaders whose national consciousness was formed during colonial times were insouciant about the presence of Hindu-Buddhist iconography and sculpture at such temples. ${ }^{49}$ Moreover, Anderson contends that the Buddhist iconography at Borobudur required neutralisation to fulfil its role in modern Indonesian heritage politics. ${ }^{50}$ The bilateral response by the Suharto administration, both using the attack as a means to denounce Islamic militants as well as secularise the site on a global platform, highlights the ability of the site to be used to meet a variety of political agendas.

44 While the perpetuation of extremist terrorism does not necessarily depict universal sentiments towards the site by the Islamic community, that there is religious dissent towards the site, albeit at the most extreme level, is worth noting.

45 R. William Liddle, 'The Islamic Turn in Indonesia: A Political Explanation', The Journal of Asian Studies 55, no. 3 (1996): 622, doi.org/10.2307/2646448.

46 Military troops fired on demonstrators at Tanjung Priok in Jakarta's dockland. The demonstrators were demanding the release of local mosque officials that were being held by troops after a confrontation at As Saadah Mosque. The mosque officials had been told to remove brochures and banners critical of the government and, upon their refusal, violent confrontation ensued, leading to the aforementioned arrests. There is discrepancy between accounts of the Tanjung Priok Massacre, with eyewitness accounts suggesting that up to several hundred people were possibly killed. Carmel Budiardjo, 'Militarism and Repression in Indonesia', Third World Quarterly 8, no. 4 (1986): 1233.

47 Institute for Policy Analysis of Conflict, 'The Anti-Shi'a Movement in Indonesia', Institute for Policy Analysis of Conflict, no. 27 (2016): 7.

48 'Bombs Explode at Buddhist Temple', United Press International, 21 January 1985 (emphasis added).

49 Bloembergen and Eickhoff, 'Conserving the Past', 431.

50 Benedict R. O'G. Anderson, 'Cartoons and Monuments: The Evolution of Political Communication under the New Order', in Political Power and Communications in Indonesia, ed. Karl D. Jackson and Lucian W. Pye (Berkley: University of California Press, 1978), 179-81. 
Borobudur's transformation from religious stūpa to national monument, according to Shelly Errington, was completed with opening of the Taman Wisata Candi Borobudur dan Prambanan [Temples of Borobudur and Prambanan Tourist Park] in $1983 .^{51}$ With the opening of the park, President Suharto announced that Buddhist ceremonies could no longer be held at Borobudur. ${ }^{52}$ Although this is the case, Borobudur continues to be marketed as a site for pilgrimage, and a number of both domestic and international Buddhists still observe Waisak (Vesik or Buddha Jayanti) at the site. Waisak observes the birth, enlightenment and death of Siddhārtha Gautama, otherwise known as Gautama Buddha, on whose teachings Buddhism was founded. The annual celebration of Waisak at Borobudur therefore contradicts the secularisation of the site. The celebration of Waisak has precedent at Borobudur irrespective of its intermittent suppression. A Star Weekly article printed in 1959 stated that the 'modern' Waisik tradition began in the 1930s, with pilgrims 'held to a confined environment'. ${ }^{53}$ The role of Borobudur as a religious sanctuary in contemporary times arises from the modularity of the site that allows it to be mobilised for a multiplicity of purposes. However, it should be considered that, in practice, there is considerable variety in how Indonesians integrate, articulate and act upon cultural nationalist ideas and, by extension, ideological discourses more broadly.

The unification of diverse ethnicities under the Indonesian nation-state necessitates a reconsideration of the history of multicultural exchange in Indonesia. The cross-cultural exchanges that have occurred historically between Hindu, Buddhist, Islamic and animist ideologies across the archipelago have had consequences on the site beyond merely temporal implications. Multiethnic religious exchanges manifest as part of a shared, collaborative past, rather than as separate histories connected through religious-political conflict. ${ }^{54}$ Therefore, the site generates a bilateral religious environment, consisting of the Buddhist site itself, and the greater multicultural connotations of the surrounding region in general. ${ }^{55}$

51 Shelly Errington, 'Making Progress on Borobudur: An Old Monument in New Order', Visual Anthropology Review 9, no. 2 (1993): 45, doi.org/10.1525/var.1993.9.2.32.

52 Errington, 'Making Progress on Borobudur', 45.

53 Keng Po, 'Borobudur Hidup Kembali Dalam Tjahaja Lilin: Djemaah Membandjir Sebagai Dalam 10 Abad Jang Lampau Perajaan Jang Berlangsung Semalam Suntuk' ['Borobudur Alive in Tjahaja Candle: Congregation Flooded as in the Past 10 Centuries, the Pilgrimage Lasted All Night Long'], Star Weekly, no. 701 (1959): 21.

54 Bloembergen and Eickhoff, 'Conserving the Past', 426.

55 Snjezana Zoric, 'The Stupa of Borobudur-A Place of Inner Pilgrimage', Spatial Practices 14 (2012): 32, doi.org/10.1163/9789401208130_003. 
To the local Muslim population, Borobudur is a site of celebration during the Idul Fitri festival that takes place at the end of Ramadhan. The Muslim community provide offerings to the Buddhist monument and perform traditional ceremonies, including wayang (shadow) puppet shows. ${ }^{56}$ The multidimensional identity of Borobudur therefore remains, for the most part, undisturbed, in spite of the oscillating nature of religious censorship by the relevant authoritative powers.

Although autonomous Indonesian governments utilised Borobudur to propagate and maintain a national identity, they were at times unsuccessful in their endeavours. A consideration of the relationship between state administration and the local community of the Borobudur region reveals the implications of cultural nationalism at the expense of local tradition. Daud A. Tanudirjo and R. Soekmono agree that, after colonial archaeological excavation, the apprehension felt towards Borobudur by those from surrounding communities was replaced with a sense of pride at the architectural accomplishments of their ancestors. ${ }^{57}$ The Indonesian Government established a centralised management policy in which the local people were marginalised. Soon after Indonesian independence, the structural integrity of Borobudur was compromised by water seepage. Borobudur was consequently declared an endangered monument. In 1972, UNESCO began an international campaign for the restoration of Borobudur. Through this campaign, a policy for the management of the site was established. The local communities surrounding Borobudur were relocated as a result of this policy and, consequently, their mosques, kiosks, cemeteries and gardens were lost. The people received minimal compensation for their requisitioned land.

Tanudirjo defines the loss of local cultural and spiritual identity as a type of landscape spoliation..$^{58}$ The establishment of an invented national identity occurred at the expense of a legitimate local one. The local community's 'grounds for discontent' were illustrated in an article published in

56 Masanori Nagaoka, 'Buffering Borobudur for Socio-Economic Development', Journal of Cultural Heritage Management and Sustainable Development 5, no. 2 (2015): 144, doi.org/10.1108/ JCHMSD-11-2013-0049.

57 Daud A. Tanudirjo, Jurusan Arkeologi and Fakultas Ilmu Budaya, 'Changing Perspectives on the Relationship between Heritage, Landscape and Local Communities: A Lesson from Borobudur', Transcending the Culture-Nature Divide in Cultural Heritage (Terra Australis 36), ed. Sally Brockwell, Sue O'Connor and Denis Byrne (Canberra: ANU Press, 2013): 66, doi.org/10.22459/ TA36.12.2013.05; R. Soekmono, Chandi Borobudur: A Monument of Mankind, English ed. (Paris: UNESCO Press, 1976), 4.

58 Tanudirjo, Arkeologi and Ilmu Budaya, 'Changing Perspectives', 70. 
Inside Indonesia, reprinted with amendments from the Human Rights Forum of January 1985. The article highlights the contention between the centralised management of the Taman Wisata Candi Borobudur dan Prambanan and surrounding communities. Director of the park H. Boediardjo offered conflicting purposes for the relocation of local communities. Initially, he suggested that the establishment of the park was primarily for tourism; however, he subsequently contradicted this sentiment, suggesting it was for the preservation of the monument and the projection of historical appreciation. ${ }^{59}$ In a declaration titled 'The Voice from the Heart of the Borobudur People', residents from surrounding villages expressed their support for the preservation of the temple for the common or national interest. ${ }^{60}$ They suggested, however, that the park be constructed on the uninhabited land to the temples north, south and west. ${ }^{61}$ Constructing the site there would ensure the occupied land to the east would not be disturbed, and the surrounding communities would not be dispossessed. Ancient building patterns situated the temple as eastern facing, and historical homage was prioritised over the petition of the local inhabitants. The stipulation of land rights repeal is articulated in Ndang-Undang Republik Indonesia Nomor 20 Tahun 1961 [Laws of the Republic Indonesia No. 20/1961]. ${ }^{62}$ The law outlines that land rights can only be repealed in an emergency. It is significant that the local communities were removed from their land in spite of this legislation, particularly when alternative uninhabited sites were available. The conflict between the local communities and the Indonesian Government that has resulted has had a negative impact on the propagation of a form of cultural nationalist ideology.

The modularity of Borobudur has allowed the site to be mobilised, consciously or otherwise, behind various philosophies and interests. These mobilisations occur irrespective of period-being passed consecutively via administration and simultaneously within sociocultural fields. While this consideration of the internal manifestations of cultural nationalism within the case study of Borobudur is by no means exhaustive, it articulates a contextual understanding of how Indonesia has mobilised the monument to achieve varying ideological agendas.

59 Kelompok Studi dan Bantuan Hukum (KSBH), 'Borobudur: Tourism Pushes out Villagers', Inside Indonesia: Bulletin of the Indonesia Resources and Information Programme (1983): 7.

$60 \mathrm{KSBH}$, 'Borobudur', 7.

$61 \mathrm{KSBH}$, 'Borobudur', 7.

$62 \mathrm{KSBH}$, 'Borobudur', 7. 


\section{External Nationalism: Indonesian Identity and the Global Community}

Cultural diplomacy aids in the assertion of an Indonesian identity within the international community of nation-states. By allowing foreign nations to develop a mutual understanding and foster relations of trust with these nations, archaeological sites appear to be effective as a means of elevating the status of post-independence Indonesia within an international context. ${ }^{63}$ Borobudur has been mobilised through cultural diplomacy to legitimise Indonesia as an independent nation-state since the early 1950s. A number of distinguished political leaders have visited Borobudur in an official capacity: Indian Prime Minister Jawaharlal Nehru, the King of Cambodia Norodom Sihanouk, Filipino President Elpidio Quirino, Prime Minister of Burma U Nu, US presidential candidate Adlai Stevenson and US Vice-President, Richard Nixon each visited the site following Indonesian independence. ${ }^{64}$ Australian Prime Minister Paul Keating attended Borobudur in 1992. Ross Peake, a political correspondent in Surabaya during Keating's visit, reported that the Australian prime minister touched a Buddha figure that, according to local folklore, would grant a wish. When asked what he hoped for, Keating said: 'Good relations between Indonesia and Australia. ${ }^{65}$ Keating's appreciation of Indonesian culture was an attempt to improve bilateral relations between the two nations. Presented publicly, both within Indonesia and in the global media, these performances aided in the legitimisation of Indonesia as a modern independent state. Through the mobilisation of Borobudur behind Indonesian cultural diplomacy, Indonesian leaders have asserted a place for the Indonesian nation-state within the global community.

Cultural diplomacy does more than simply facilitate an awareness of Indonesia's maintenance of its Buddhist heritage. Artistic experience acts as a vehicle for cross-cultural communication. Highlighting the commonalities of aesthetic awareness inspires respect and trust between nations. Borobudur's sui generis architecture, bas-reliefs and sculpture typify an artistic experience of the national history that Indonesia is

63 John Lenczowski, 'Cultural Diplomacy, Political Influence \& Integrated Strategy', in Strategic Influence: Public Diplomacy, Counterpropaganda, and Political Warfare, ed. J. Michael Waller (Washington: The Institute of World Politics Press, 2008), 89.

64 Bloembergen and Eickhoff, 'Conserving the Past', 406.

65 Ross Peake, 'PM touches Buddha for Luck', Canberra Times, 24 April 1992, 2. 
attempting to portray to a global audience. The museum-isation of the temple allows the site to act as an exhibition space in the field of cultural diplomacy. Borobudur goes beyond the aforementioned visible aesthetic awareness, connoting elements of culture, science, technology, commercialisation and local customs. ${ }^{66}$ These connotations can be used to convey interpretations of Indonesian national identity and foster a deeper level of understanding between nation-states. Emphasis is placed on cultural diplomacy, as it allows for agendas to be perpetuated without the preconceptions of political discourse. ${ }^{67}$ By opening Borobudur as a diplomatic site, Indonesia is able to legitimise its status as a modern nation while simultaneously perpetuating a national image based on tradition.

Nationalism is central to Indonesia's worldview. A culmination of anticolonial discourse and the subsequent struggle for independence and cultural unification form Indonesia's national identity. Paige Johnson Tan suggests that, by virtue of Indonesia's location, cultural heritage and expansiveness, its leaders have sought political and economic progression in the pan-Asian context. ${ }^{68}$ Former President Susilo Bambang Yudhoyono (2004-14) described Indonesia's foreign policy as its 'international identity'. ${ }^{69}$ The role of Borobudur in asserting a place for the Indonesian nation extends beyond its cultural associations. The religious significance of the site and its connection to ancient Indian civilisations through the Sailendra dynasty simultaneously strengthen and complicate the politics of nation building. The aforementioned diplomatic visitors attended the site to honour the new nation-state; however, the associations of Borobudur with Buddhism and ancient Indian civilisation may supersede the national identity being perpetuated. ${ }^{70}$ This association is apparent when considering the illustrations of Jätaka, avadāna and sütra depicted on the walls of the Borobudur temple. The articulations of these reliefs facilitate a connection with Buddhist literature and iconography beyond the site itself. The Sanskrit verse from the Bhadracari, illustrated on the uppermost series of reliefs at Borobudur, is also articulated didactically on the base of the Nālandā monastery in northern India. As these are the only

66 Lenczowski, 'Cultural Diplomacy', 88.

67 Lenczowski, 'Cultural Diplomacy', 88.

68 Paige Johnson Tan, 'Navigating a Turbulent Ocean: Indonesia’s Worldview and Foreign Policy',

Asian Perspective 31, no. 3 (2007): 147.

69 Tan, 'Navigating a Turbulent Ocean', 148.

70 Bloembergen and Eickhoff, 'Conserving the Past', 406. 
known articulations of the text architecturally, the sites are able to inform a deeper understanding of each other. The historical implications of crosscultural exchange that transferred Buddhist philosophy throughout the region create emotional legitimacies between Borobudur temple and the Nālandā monastery. This exchange has implications more broadly for Indonesian and Indian Buddhist archaeology and architecture beyond geographical parameters. These historical and religious associations may also establish complex understandings between Indonesia and these transnational visitors. Borobudur therefore establishes historical and religious affiliations with nations who share this heritage. The implications of this in the perpetuation of a national identity are equivocal, establishing mutual understanding between these nations but also diluting the significance of the site within Indonesian borders.

International tourism plays a significant role in perpetuation of a national identity, portraying how a country wishes to be perceived through highly contested and carefully constructed realities. During the mid1990 s, Borobudur received around 2.5 million visitors annually. ${ }^{71}$ While 80 per cent of these tourists were domestic, Borobudur's tourism and heritage administration focused primarily on international visitors. ${ }^{72}$ The classification of Borobudur Temple Compound as a UNESCO world heritage site in 1991 asserted a place for the Indonesian nationstate within the global community at the expense of local support. The aforementioned UNESCO management policy fostered parochialist sentiments between the central authoritative bodies that govern the site and the local communities that surround it. ${ }^{73}$ These sentiments have the capacity, in certain instances, to undermine Indonesia's reputation within the global community. This is apparent through a consideration of the 1985 article, 'Borobudur: Tourism Pushes Out Visitors', printed in the Australian-based journal Inside Indonesia and written in response to the centralised management policy. ${ }^{74}$ By disseminating these sentiments and bringing the legal and ethical injustices experienced by local communities to the attention of an international audience, articles such as this highlight the impact of Borobudur's centralised management program globally. The importance successive Indonesian administrations have attached to

71 Hampton, 'Heritage, Local Communities and Economic Development', 736.

72 Hampton, 'Heritage, Local Communities and Economic Development', 736.

73 Tanudirjo, Arkeologi and Ilmu Budaya, 'Changing Perspectives', 66.

$74 \mathrm{KSBH}$, 'Borobudur', 7-8. 
the site's global respectability is a legitimating factor of their nationhood. Yet, when it occurs at the expense of the local community, the results can be counterproductive.

Borobudur has a central role in the perpetuation of a legitimate Indonesian nation-state within the global community. The importance attached to cultural diplomacy and cross-cultural exchange by successive administrations, as well as the emphasis on tourism, has portrayed Indonesia as the custodian of a glorified past to a global audience. The propagation of Borobudur as an Indonesian icon on a global scale has allowed the Republic of Indonesia to legitimise its status as a modern nation.

The modularisation of Borobudur that occurred during the colonial period has facilitated its use for cultural nationalism. Through the establishment of a concurrently inward- and outward-facing nationalist identity, Borobudur has maintained the unification of heterogeneous populations within national borders while concurrently asserting a place for the Republic of Indonesian within the global community. The disinterment of the site, and its subsequent transformation into an iconised archaeological monument by the Dutch, created a recognisable heritage easily inherited by the Indonesian nation-state. From an internal perspective, Borobudur has been mobilised by successive-and, at times, simultaneous - groups and administrations to bolster a nationalist identity and create emotional legitimacy for the Indonesian nation-state. Borobudur has a fundamental role in authenticating Indonesia within the global community. Cultural diplomacy aids in the assertion of an Indonesian identity within the international community of nation-states. The site is therefore utilised to emphasise and legitimise multiple variants of a national consciousness on a local, national and global scale.

Although historical implications may confine Borobudur's contemporary role to that of an archaeological monument, this consideration incites an interpretation of cultural nationalist identity as it manifests in Indonesian society beyond that of accepted historical continuities. By considering this with regard to the nationalist ideology more broadly, it becomes apparent that a greater cultural consciousness is imperative in an understanding of how nationalist ideology is disseminated in nation-states and how heritage sites are utilised by administrations to achieve a specific agenda. 
This text is taken from ANU Historical Journal II: Number 2, published 2020 by ANU Press, The Australian National University, Canberra, Australia.

doi.org/10.22459/ANUHJII.2020.06 